\title{
Jouna of Oeuroscience
}

The Official Journal of the Society for Neuroscience
November 1, 2000

Volume 20 Number 21

Rapid Communications are available online only.

\section{Rapid Communications (http://www.jneurosci.org)}

RC104(1-5) Neurotrophic Factor Expression After CNS Viral Injury Produces Enhanced Sensitivity to Psychostimulants: Potential Mechanism for Addiction Vulnerability Marylou V. Solbrig, George F. Koob, Loren H. Parsons, Tomoko Kadota, Nigel Horscroft, Thomas Briese, and W. Ian Lipkin

RC105(1-5) Bradykinin, But Not Muscarinic, Inhibition of M-Current in Rat Sympathetic Ganglion Neurons Involves Phospholipase C- $\beta 4$

Jane E. Haley, Fe C. Abogadie, Jose M. Fernandez-Fernandez, Mariza Dayrell, Yvonne Vallis, Noel J. Buckley, and David A. Brown

\section{Articles}

\section{Cellular/Molecular}

7863 Phorbol Esters Potentiate Evoked and Spontaneous Release by Different Presynaptic Mechanisms Jack Waters and Stephen J Smith

7871 Activation of Metabotropic Glutamate Receptor 5 Has Direct Excitatory Effects and Potentiates NMDA Receptor Currents in Neurons of the Subthalamic Nucleus Hazar Awad, George W. Hubert, Yoland Smith, Allan I. Levey, and P. Jeffrey Conn

7880 Long-Term Potentiation Induced by $\theta$ Frequency Stimulation Is Regulated by a Protein Phosphatase-1-Operated Gate George P. Brown, Robert D. Blitzer, John H. Connor, Tony Wong, Shirish Shenolikar, Ravi Iyengar, and Emmanuel M. Landau

7888 Reduction in the Density and Expression, But Not G-Protein Coupling, of Serotonin Receptors $\left(5-\mathrm{HT}_{1 \mathrm{~A}}\right)$ in 5-HT Transporter Knock-Out Mice: Gender and Brain Region Differences

Qian Li, Christine Wichems, Armin Heils, Klaus-Peter Lesch, and Dennis L. Murphy

7896 Selective Blockade of P/Q-Type Calcium Channels by the Metabotropic Glutamate Receptor Type 7 Involves a Phospholipase C Pathway in Neurons

Julie Perroy, Laurent Prezeau, Michel De Waard, Ryuichi Shigemoto, Joel Bockaert, and Laurent Fagni

7905 Role of Bicarbonate and Chloride in GABA- and Glycine-Induced Depolarization and $\left[\mathrm{Ca}^{2+}\right]_{\mathrm{i}}$ Rise in Fetal Rat Motoneurons In Situ Anna Kulik, Hiroshi Nishimaru, and Klaus Ballanyi

7914 Slow Desensitization Regulates the Availability of Synaptic GABA Receptors $^{2}$ Linda S. Overstreet, Mathew V. Jones, and Gary L. Westbrook

7922 Developmental Changes in Synaptic AMPA and NMDA Receptor Distribution and AMPA Receptor Subunit Composition in Living Hippocampal Neurons Lisa Pickard, Jacques Noël, Jeremy M. Henley, Graham L. Collingridge, and Elek Molnar 
Regulation of AMPA Receptor GluR1 Subunit Surface Expression by a 4.1N-Linked Actin Cytoskeletal Association

Lei Shen, Feng Liang, Loren D. Walensky, and Richard L. Huganir

Novel SCAMPs Lacking NPF Repeats: Ubiquitous and Synaptic Vesicle-Specific Forms Implicate SCAMPs in Multiple Membrane-Trafficking Functions

Rafael Fernández-Chacón and Thomas C. Südhof

Mice with Combined Gene Knock-Outs Reveal Essential and Partially Redundant Functions of Amyloid Precursor Protein Family Members

Sabine Heber, Jochen Herms, Vladan Gajic, Johannes Hainfellner, Adriano Aguzzi,

Thomas Rülicke, Hans Kretzschmar, Cornelia von Koch, Sangram Sisodia, Phillippe Tremml, Hans-Peter Lipp, David P. Wolfer, and Ulrike Müller

7964 Tumor Necrosis Factor $\alpha$ Induces a Metalloprotease-Disintegrin, ADAM8 (CD 156): Implications for Neuron-Glia Interactions during Neurodegeneration Uwe Schlomann, Silvia Rathke-Hartlieb, Shunsuke Yamamoto, Harald Jockusch, and Jörg W. Bartsch

7972 Constitutive Endocytosis of $\mathrm{GABA}_{\mathrm{A}}$ Receptors by an Association with the Adaptin AP2 Complex Modulates Inhibitory Synaptic Currents in Hippocampal Neurons Josef T. Kittler, Patrick Delmas, Jasmina N. Jovanovic, David A. Brown, Trevor G. Smart, and Stephen J. Moss

In Situ $\mathrm{Ca}^{2+}$ Imaging Reveals Neurotransmitter Receptors for Glutamate in Taste Receptor Cells

Alejandro Caicedo, M. Samir Jafri, and Stephen D. Roper

Clathrin-Mediated Endocytosis near Active Zones in Snake Motor Boutons

Haibing Teng and Robert S. Wilkinson

Apoptosis Has a Prolonged Role in the Neurodegeneration after Hypoxic Ischemia in the Newborn Rat

Wako Nakajima, Akira Ishida, Mary S. Lange, Kathleen L. Gabrielson, Mary Ann Wilson, Lee J. Martin, Mary E. Blue, and Michael V. Johnston

8005 NMDA But Not Non-NMDA Excitotoxicity is Mediated by Poly(ADP-Ribose) Polymerase Allen S. Mandir, Marc F. Poitras, Adam R. Berliner, William J. Herring, Daniel B. Guastella, Alicia Feldman, Guy G. Poirier, Zhao-Qi Wang, Ted M. Dawson, and Valina L. Dawson

\section{Development/Plasticity/Repair}

8012 A Glia-Derived Signal Regulating Neuronal Differentiation Olivier Blondel, Carlos Collin, William J. McCarran, Shiaoping Zhu, Rachel Zamostiano, Illana Gozes, Douglas E. Brenneman, and Ronald D. G. McKay

8021 Cell Migration and Aggregation in the Developing Telencephalon: Pulse-Labeling Chick Embryos with Bromodeoxyuridine Georg F. Striedter and Brian P. Keefer

8031 A Purine-Sensitive Pathway Regulates Multiple Genes Involved in Axon Regeneration in Goldfish Retinal Ganglion Cells

Barbara Petrausch, Raymond Tabibiazar, Timo Roser, Yun Jing, Daniel Goldman, Claudia A. O. Stuermer, Nina Irwin, and Larry I. Benowitz

8042 PAX6 Modulates the Dorsoventral Patterning of the Mammalian Telencephalon A. Stoykova, D. Treichel, M. Hallonet, and P. Gruss

Activity-Dependent Patterning of Retinogeniculate Axons Proceeds with a Constant Contribution from AMPA and NMDA Receptors

Carsten D. Hohnke, Serkan Oray, and Mriganka Sur

8061 Regeneration of Lesioned Corticospinal Tract Fibers in the Adult Rat Induced by a Recombinant, Humanized IN-1 Antibody Fragment

Christian Brösamle, Andrea B. Huber, Markus Fiedler, Arne Skerra, and Martin E. Schwab 
Potassium-Coupled Chloride Cotransport Controls Intracellular Chloride in Rat Neocortical Pyramidal Neurons

R. Anthony DeFazio, Sotirios Keros, Michael W. Quick, and John J. Hablitz

Transmitter-Receptor Interactions between Growth Cones of Identified Lymnaea Neurons Determine Target Cell Selection In Vitro

Gaynor E. Spencer, Ken Lukowiak, and Naweed I. Syed

Neuronal Activity and Brain-Derived Neurotrophic Factor Regulate the Density of Inhibitory Synapses in Organotypic Slice Cultures of Postnatal Hippocampus

Serge Marty, Rosine Wehrlé, and Constantino Sotelo

\section{Behavioral/Systems}

8096 Parallel Instabilities of Long-Term Potentiation, Place Cells, and Learning Caused by Decreased Protein Kinase A Activity

Alexander Rotenberg, Ted Abel, Robert D. Hawkins, Eric R. Kandel, and Robert U. Muller

8103 Muscarinic Tone Sustains Impulse Flow in the Septohippocampal GABA But Not Cholinergic Pathway: Implications for Learning and Memory Meenakshi Alreja, Min Wu, Weimin Liu, Joshua B. Atkins, Csaba Leranth, and Marya Shanabrough

8111 Long-Term Optical Imaging and Spectroscopy Reveal Mechanisms Underlying the Intrinsic Signal and Stability of Cortical Maps in V1 of Behaving Monkeys

Eran Shtoyerman, Amos Arieli, Hamutal Slovin, Ivo Vanzetta, and Amiram Grinvald

Intra-Accumbens Amphetamine Increases the Conditioned Incentive Salience of Sucrose Reward: Enhancement of Reward "Wanting" without Enhanced "Liking" or Response Reinforcement Cindy L. Wyvell and Kent C. Berridge

8131 Antagonism of the Melanocortin System Reduces Cold and Mechanical Allodynia in Mononeuropathic Rats Dorien H. Vrinten, Willem Hendrik Gispen, Gerbrand J. Groen, and Roger A. H. Adan

8138 The Circadian Clock Mutation Alters Sleep Homeostasis in the Mouse Erik Naylor, Bernard M. Bergmann, Kristyn Krauski, Phyllis C. Zee, Joseph S. Takahashi, Martha Hotz Vitaterna, and Fred W. Turek

8144 Using Fos Imaging in the Rat to Reveal the Anatomical Extent of the Disruptive Effects of Fornix Lesions

Seralynne D. Vann, Malcolm W. Brown, Jonathan T. Erichsen, and John P. Aggleton

Interleukin- $1 \beta$-Induced Changes in Blood-Brain Barrier Permeability, Apparent Diffusion Coefficient, and Cerebral Blood Volume in the Rat Brain: A Magnetic Resonance Study A. M. Blamire, D. C. Anthony, B. Rajagopalan, N. R. Sibson, V. H. Perry, and P. Styles

8160 Reduction of Pentylenetetrazole-Induced Seizure Activity in Awake Rats by SeizureTriggered Trigeminal Nerve Stimulation

Erika E. Fanselow, Ashlan P. Reid, and Miguel A. L. Nicolelis

8169 A Cellular Mechanism for the Transformation of a Sensory Input into a Motor Command Gonzalo Viana Di Prisco, Edouard Pearlstein, Didier Le Ray, Richard Robitaille, and Réjean Dubuc

Activation of ERK/MAP Kinase in the Amygdala Is Required for Memory Consolidation of Pavlovian Fear Conditioning

Glenn E. Schafe, Coleen M. Atkins, Michael W. Swank, Elizabeth P. Bauer, J. David Sweatt, and Joseph E. LeDoux

8188 Visual Responses in Monkey Areas V1 and V2 to Three-Dimensional Surface Configurations Jonathan S. Bakin, Ken Nakayama, and Charles D. Gilbert

8199 Neural Correlates of Olfactory Recognition Memory in the Rat Orbitofrontal Cortex Seth J. Ramus and Howard Eichenbaum 
8218 Developmental Changes in Eye-Blink Conditioning and Neuronal Activity in the Inferior Olive

Daniel A. Nicholson and John H. Freeman Jr

Correction

Cover picture: Rendering of a snake motor bouton from 31 serial electron microscopy sections reveals that endocytic sites are near active zones. The bouton was cooled to $7^{\circ} \mathrm{C}$ and briefly stimulated in the presence of the endocytic probe FM1-43. The probe was then photoconverted into an electron-dense marker. Endocytosed clathrin-coated vesicles (white) containing FM1-43 remained near their sites of internalization because of low temperature. These sites were near active zones (red) scattered within the presynaptic membrane (yellow). The postsynaptic folds of the innervated muscle fiber are shown blue. A Schwann cell that capped the bouton is pink, whereas endosomes within the bouton are gray. For details, see the article by Teng and Wilkinson in this issue (pages 7986-7993).

Corrections: In the article "Functional Uncoupling of Adenosine $\mathrm{A}_{2 \mathrm{~A}}$ Receptors and Reduced Response to Caffeine in Mice Lacking Dopamine $\mathrm{D}_{2}$ Receptors," by Nancy R. Zahniser, Johanna K. Simosky, R. Dayne Mayfield, Cori A. Negri, Taleen Hanania, Gaynor A. Larson, Michele A. Kelly, David K. Grandy, Marcelo Rubinstein, Malcolm J. Low, and Bertil B. Fredholm, which appeared on pages 5949-5957 of the August 15, 2000 issue, the adenyl cyclase probe used is directed to cyclase type V, not VI as erroneously stated in the paper. The authors apologize for this oversight but are confident that the erroneous designation does not alter any of the conclusions drawn.

In the article "Neuronal Basic Helix-Loop-Helix Proteins (NEX and BETA2/Neuro D) Regulate Terminal Granule Cell Differentiation in the Hippocampus," by Markus H. Schwab, Angelika Bartholomae, Bernd Heimrich, Dirk Feldmeyer, Silke Druffel-Augustin, Sandra Goebbels, Frank J. Naya, Shanting Zhao, Michael Frotscher, Ming-Jer Tsai, and Klaus-Armin Nave, which appeared on pages 3714-3724 of the May 15, 2000 issue, the lower left graph of Figure $5 C$ [the IV curve of a control wild-type granule cell in the dentate gyrus $(D G)$ ] is a duplication of another curve just above it [a control wild-type pyramidal cell $(C A 3)]$. The correct version of the figure, as well as the legend, is printed in this issue.

Persons interested in becoming members of the Society for Neuroscience should contact the Membership Department, Society for Neuroscience, 11 Dupont Circle, NW, Suite 500, Washington, DC 20036, phone 202-462-6688.

Instructions for Authors appear at the end of the January 1, 2000 issue. Copies of the Instructions can be obtained by writing to The Journal of Neuroscience, Society for Neuroscience, 11 Dupont Circle, NW, Suite 500, Washington, DC 20036, phone 202-4626688, fax 202-462-1547, e-mail jn@sfn.org. The Instructions are also available via Internet (http://www.jneurosci.org/misc/itoa.shtml). Rapid Communications Instructions for Authors appear at the end of the January 15, 1999 issue and are also available via Internet (http://www.sfn.org/RapidComm/ifa.html). Submissions should be sent to the above address. Scientific inquiries concerning manuscripts can be made directly to Dr. Gordon M. Shepherd, Editor-in-Chief, The Journal of Neuroscience, Section of Neurobiology, Yale University School of Medicine, 333 Cedar Street, New Haven, CT 06510, phone 203-785-4336, fax 203-785-6990, e-mail jneurosci@yale.edu.

The Journal of Neuroscience requests that authors send a disk containing an electronic file of their manuscript with each submission. Most word processing software can be used; see the Instructions for Authors for detailed guidelines on acceptable disk and file formats. 